\title{
PROFIL PEMBELAJARAN MEMBACA PEMAHAMAN OLEH GURU BAHASA JEPANG DI SMAN 4 SINGARAJA
}

\author{
W. S. Handika ${ }^{1}$, I. W. Sadyana ${ }^{2}$, K. E. K. Adnyani ${ }^{3}$ \\ Jurusan Pendidikan Bahasa Jepang, \\ Universitas Pendidikan Ganesha \\ Singaraja, Indonesia \\ e-mail: handikawely@gmail.com \\ wayan.sadyana@undiksha.ac.id krishna.adnyani@undiksha.ac.id
}

\begin{abstract}
Abstrak
Penelitian ini bertujuan untuk mengetahui (1) pembelajaran membaca pemahaman bahasa Jepang di SMAN 4 Singaraja, (2) kendala-kendala yang dihadapi guru dalam pembelajaran membaca pemahaman bahasa Jepang, (3) upaya guru untuk mengatasi kendala dalam pembelajaran membaca pemahaman bahasa Jepang. Subjek penelitian ini adalah guru bahasa Jepang SMAN 4 Singaraja. Pengumpulan data dilakukan dengan metode observasi, dokumentasi, dan wawancara, kemudian dianalisis dengan metode deskriptif kualitatif. Hasil penelitian menunjukkan bahwa (1) pembelajaran membaca pemahaman merupakan bagian dari ouyou renshuu dengan strategi membaca Bottom-Up dan menggunakan media pembelajaran berupa aplikasi Microsoft Powerpoint yang ditampilkan pada layar LCD, (2) kendala yang dialami oleh guru dalam proses membaca pemahaman yaitu kurangnya bahan ajar untuk membaca pemahaman pada buku pedoman dan masih sulit memotivasi siswa karena karakteristik siswa yang berbeda-beda, (3) upaya guru untuk mengatasi kendala adalah memberikan banyak latihan membaca tulisan hiragana, katakana, dan kanji baik berupa kosa kata dan kalimat sederhana serta mencari bahan ajar melalui internet.
\end{abstract}

Kata kunci : Profil, Pembelajaran Membaca Pemahaman, kana.

要旨

本研究の目的は、（1）公立シンガラジャ第四高等学校における読解学習、（2）日本語教師 が読解学習の際に直面する問題点、（3）教師が直面する問題点の解決方法を明らかにする ことである。対象は、公立シンガラジャ第四高等学校の日本語教師である。データは、授業 観察、記録撮影、インタビューにより収集し、それを定性的記述法により分析した。結果、

（1）読解学習は、ボトムアップを図るための忘用練習の一部であり、LCDにパワーポイン 卜を写し出し教材として利用している。（2）読解学習を指導する際に直面寸る問題として 、読解学習用の教科書および副教材の不足、生徒に様々な個性があるため動機づけするのが 難しいことが挙げられる。（3）問題点を解決するため、簡単な語彙と文章によるひらがな 、かたかな、漢字を読む練習を充分に行い、不足する教材においてインターネットなどから 教材を探し克服している。

キーワード : プロフィール、読解学習、ひらがな、かたかな 


\section{Pendahuluan}

Bahasa Jepang merupakan mata pelajaran tambahan di beberapa sekolah yang ada di Indonesia. Depdiknas mengatakan bahwa mata pelajaran bahasa Jepang merupakan mata pelajaran pilihan di Sekolah Menengah Atas (SMA) yang berfungsi sebagai alat pengembangan diri siswa dalam bidang ilmu pengetahuan, teknologi, dan seni budaya. Oleh sebab itu, beberapa sekolah di Indonesia memasukkan pelajaran bahasa Jepang sebagai pelajaran tambahan.

Aspek keterampilan berbahasa yang harus dicapai oleh siswa yaitu ketrampilan membaca, berbicara, mendengarkan, dan menulis. Setiap guru bahasa harus menyadari bahwa membaca merupakan ketrampilan yang kompleks atau rumit (Tarigan, 1979:10). Dalam pembelajaran bahasa Jepang, guru diharapkan mampu mengajarkan pembelajaran membaca dengan baik kepada siswa sehingga mampu menguasai kecakapan dalam membaca, seperti halnya membaca teks bahasa Jepang dengan baik, karena dengan penguasaan membaca yang baik siswa dapat mengerti maksud yang disampaikan dalam wacana yang diberikan. Menurut Nurkamilah et al. (2016) dalam pembelajaran bahasa Jepang seringkali siswa mengalami kesulitan dalam membaca dan memahami isi bacaan karena banyaknya huruf, kosa kata, dan pola kalimat bahasa Jepang. Dalam membaca siswa tidak hanya membaca saja melainkan harus memahami isi bacaan tersebut.

Berdasarkan hasil wawancara dengan guru bahasa Jepang di SMAN 4 Singaraja didapatkan hasil bahwa siswa mengalami kendala dalam membaca bacaan bahasa Jepang. Kendala tersebut dalam huruf-huruf bahasa Jepang seperti huruf kana dan kanji, selain itu kendala terletak pada kosa kata dan pola kalimat bahasa Jepang, sehingga hal tersebut membuat siswa kesulitan untuk membaca dan memahami kalimat atau wacana bahasa Jepang. Namun kendala tersebut dapat diatasi dengan memberikan banyak latihan membaca huruf, kosa kata dan kalimat bahasa Jepang sehingga siswa terbiasa membaca kosa kata dan kalimat bahasa Jepang serta mampu memahami kalimat tersebut.

Kendala-kendala yang memengaruhi kemampuan membaca pemahaman siswa rendah berasal dari faktor siswa itu sendiri dan strategi guru dalam mengajar di kelas. Menurut Sriwulan dkk (2014) hasil belajar membaca pemahaman bahasa Jepang siswa dipengaruhi oleh faktor intern siswa yaitu kemampuan kognitif penguasaan perbendaharaan kata, struktur, dan memahami wacana serta minat, motivasi dan percaya diri siswa kemudian faktor ektern yang meliputi model pembelajaran, metode, strategi yang digunakan guru serta sarana belajar dan lingkungan belajar siswa.

Membaca pemahaman merupakan salah satu keterampilan yang kompleks. Keterampilan ini memengaruhi perasaan dan emosi siswa dalam menangkap serta menyimpulkan isi yang disampaikan pada wacana, sehingga dalam pembelajaran membaca pemahaman dibutuhkan motivasi dalam diri pembaca untuk dapat memahami isi bacaan yang diberikan. Warner et al. (2017) mengatakan bahwa pemahaman membaca adalah kegiatan mandiri yang tergantung pada upaya proaktif dari pembaca dan membutuhkan keterampilan kognitif yang lebih tinggi, mengidentifikasi arti kata, secara aktif membangun makna dan informasi dalam teks, sehingga siswa harus memiliki motivasi dan pemikiran yang tinggi agar dapat memahami makna yang terkandung dalam teks yang diberikan. Motivasi dan minat baca siswa sangat memengaruhi kemampuan membaca pemahaman siswa. Romafi dan Musfiroh (2015) menyatakan dalam hasil penelitian yang dilakukan bahwa hubungan antara minat membaca siswa terhadap kemampuan membaca pemahaman siswa memiliki hubungan yang positif dan signifikan. Selain itu peran aktif guru juga sangat dibutuhkan untuk menumbuhkan dan meningkatkan motivasi siswa terhadap pembelajaran membaca pemahaman dalam kelas.

Salah satu komponen yang perlu dicermati adalah masalah strategi pembelajaran membaca pemahaman yang digunakan oleh guru di kelas. Penerapan strategi yang tidak monoton dan efektif sangat menunjang keaktifan siswa dalam proses belajar. Tarigan (1979) berpendapat bahwa keadaan pengajaran bahasa yang di dalamnya inklusif pengajaran membaca belum berjalan dengan mulus, efisien, dan efektif. Maka, dapat dikatakan bahwa pembelajaran 
membaca yang dilakukan guru saat ini belum mampu menerapkan strategi pembelajaran membaca dengan efektif untuk menunjang keberhasilan siswa dalam mewujudkan tujuan pembelajaran dengan baik.

Perbaikan strategi pembelajaran membaca yang sesuai dan relevan merupakan salah satu solusi alternatif yang dapat dilakukan oleh guru untuk mencapai tujuan pembelajaran dengan baik. Untuk bisa menentukan strategi pembelajaran membaca, seorang guru diharapkan memahami dan mengetahui strategi dalam menyajikan materi pembelajaran membaca pemahaman. Dengan demikian keahlian guru dalam memilih strategi pembelajaran membaca diharapkan dapat menyesuaikan dengan situasi dan kondisi siswa untuk mencapai tujuan pembelajaran membaca pemahaman. Dengan begitu dipandang perlu untuk melakukan penelitian terhadap proses pembelajaran yang dilakukan oleh guru di kelas.

Oleh sebab itu, dipilihlah subjek penelitian guru bahasa Jepang di SMAN 4 Singaraja. SMA Negeri 4 Singaraja dipilih sebagai lokasi penelitian karena sekolah tersebut memiliki seorang guru yang senior dan berpengalaman dalam hal mengajarkan bahasa Jepang. Pengalaman mengajar guru dimulai dari tahun 2001 sampai sekarang. SMAN 4 Singaraja juga merupakan salah satu sekolah berprestasi di Singaraja dan telah berhasil meraih beberapa prestasi dalam hal perlombaan dibidang akademik pada prodi bahasa Jepang. Adapun juara yang pernah diraih yakni juara 1 dan harapan 1 roudoku contest di UNDIKSHA pada tahun ajaran 2014/2015, juara 1 roudoku contest di UNDIKSHA pada tahun ajaran 2013/2014, dan juara harapan 1 roudoku contest di UNDIKSHA pada tahun ajaran 2012/2013. Prestasi lainnya adalah juara 2 speech contest di UNDIKSHA, juara 1 story telling di STIBA, juara 2 story telling, dan juara 2 speech contest di Universitas Udayana.

Berdasarkan hasil wawancara dengan guru bahasa Jepang di SMAN 4 Singaraja mengatakan pelatihan membaca pemahaman dilakukan dengan memberikan siswa lembar kerja yang berisi wacana bahasa Jepang selain itu juga guru memberikan kosakata baru bahkan membaca kalimat bahasa Jepang yang ditampilkan di LCD. Kemudian guru juga menerapkan variasi mengajar yang berbeda-beda disesuaikan dengan karakteristik siswa di setiap kelas. Tidak hanya itu, siswa yang memiliki kemampuan baik dalam pelajaran bahasa Jepang dipilih untuk mengikuti KSBK yang sejenis dengan Japanese Club, kemudian siswa yang terpilih dalam club ini akan dikirim di setiap perlombaan berbahasa Jepang seperti cerdas cermat bahasa Jepang, Rodouku Contest, story telling serta membaca huruf kana maupun kanji.

Pada hasil pengamatan terlihat bahwa dalam proses pembelajaran membaca pemahaman di kelas, guru terlebih dahulu memahami karakteristik siswa dan kemampuan siswa kemudian memilih strategi pembelajaran membaca yang sesuai dengan kemampuan siswa. Siswa SMAN 4 Singaraja masih tergolong pebelajar pemula sehingga guru memilih strategi membaca Bottom Up sebagai strategi pembelajaran yang tepat dan efektif untuk siswa karena membaca dengan Bottom Up merupakan model membaca ditujukan kepada pebelajar pemula, proses pemahaman siswa dimulai dari tataran bahasa yang terkecil menuju tataran yang terbesar atau tinggi yaitu memulai memahami kosa kata, kalimat, menuju kepada pemahaman paragraf. Pada tahap latihan membaca di kelas, guru sering kali menunjuk siswa yang memiliki kemampuan baik di kelas untuk mengawali latihan membaca dan mencoba menjawab pertanyaan. Hal ini dilakukan guru agar memberi gambaran atau contoh kepada siswa yang lain untuk mencoba latihan yang diberikan guru dan menjadi motivasi kepada siswa yang memiliki kemampuan kurang sehingga terpacu dalam proses pembelajaran di kelas.

Penelitian tentang pembelajaran membaca pernah dilakukan oleh Ananda et al. (2016) menyatakan hasil penelitian bahwa hasil nilai koefisien korelasi sebesar 0,91 yang menunjukkan bahwa terdapat hubungan yang signifikan antara penggunaan strategi membaca selektif dengan kemampuan pemahaman membaca dokkai dan sebesar $82 \%$ tingkat pemahaman membaca teks dokkai dipengaruhi oleh strategi membaca dan $18 \%$ oleh faktor lain, sehingga dapat disimpulkan bahwa penggunaan strategi membaca memiliki hubungan positif terhadap prestasi pemahaman membaca. 
Berdasarkan paparan diatas, maka dipandang perlu melakukan penelitian pembelajaran membaca pemahaman oleh guru di SMAN 4 Singaraja untuk mengamati proses pembelajaran membaca pemahaman bahasa Jepang dasar. Oleh sebab itu, hendak dilakukan penelitian yang berjudul "Profil Pembelajaran Membaca Pemahaman oleh Guru Bahasa Jepang di SMAN 4 Singaraja". Hasil penelitian ini diharapkan dapat memberikan gambaran tentang pembelajaran membaca pemahaman oleh guru bahasa Jepang, sehingga berkontribusi terhadap kemampuan guru, terutama guru mata pelajaran bahasa Jepang dalam pemilihan strategi mengajar yang tepat dan efektif untuk pembelajaran membaca pemahaman dengan menyesuaikan dan memahami karakteristik siswa sehingga mampu mencapai tujuan pembelajaran yang sudah ditetapkan. berikut.

Berdasarkan latar belakang diatas, diajukan beberapa rumusan masalah, sebagai

1. Bagaimana profil pembelajaran membaca pemahaman oleh guru bahasa Jepang di SMAN 4 Singaraja?

2. Apa kendala-kendala yang dialami guru dalam pembelajaran membaca pemahaman bahasa Jepang di SMAN 4 Singaraja?

3. Bagaimana upaya guru untuk mengatasi kendala-kendala dalam pembelajaran membaca pemahaman bahasa Jepang di SMAN 4 Singaraja?

Berdasarkan rumusan masalah diatas, adapun tujuan penelitian ini, yaitu.

1. Untuk mengetahui bagaimana pembelajaran membaca pemahaman oleh guru bahasa Jepang di SMAN 4 Singaraja.

2. Untuk mengetahui kendala-kendala yang dialami guru dalam pembelajaran membaca pemahaman di SMAN 4 Singaraja.

3. Untuk mengetahui upaya guru untuk mengatasi kendala-kendala dalam pembelajaran membaca pemahaman bahasa Jepang di SMAN 4 Singaraja.

\section{Metode}

Penelitian ini menggunakan pendekatan deskriptif-kualitatif. Menurut Bungin (2009:68) penelitian deskriptif-kualitatif merupakan penelitian yang bertujuan untuk menggambarkan, meringkaskan, berbagai kondisi, berbagai situasi, atau berbagai fenomena realitas sosial yang ada di masyarakat yang menjadi objek penelitian, dan berupaya menarik realitas itu ke permukaan sebagai suatu cirri, karakter, sifat, model, tanda, atau gambaran tentang kondisi, situasi, ataupun fenomena tertentu. Dengan demikian, dapat dikatakan bahwa penelitian deskriptif-kualitatif adalah penelitian yang digunakan untuk memperoleh gambaran yang jelas mengenai kondisi, situasi, dan fakta-fakta yang didapat dari lapangan atau objek penelitian.

Penelitian ini dilakukan di SMA Negeri 4 Singaraja yang berlokasi di jalan Melati, Singaraja. Sumber data dalam penelitian ini adalah kata-kata dan tindakan guru bahasa Jepang SMA Negeri 4 Singaraja dalam pembelajaran membaca pemahaman di kelas. Data diperoleh melalui observasi proses pembelajaran membaca pemahaman dan wawancara, serta data dokumentasi berupa foto kegiatan pembelajaran membaca pemahaman oleh guru bahasa Jepang SMA Negeri 4 Singaraja.

Analisis data dilakukan setiap saat pengumpulan data di kelas secara berkesinambungan. Sugiyono (2012) mengatakan bahwa kegiatan dalam analisis data adalah mengelompokkan data berdasarkan variabel dan jenis responden, mentabulasi data berdasarkan variabel dari seluruh responden, menyajikan data tiap variabel yang diteliti, melakukan perhitungan untuk menguji hipotesis yang telah diajukan.

Dalam penelitian ini, data-data diperoleh dari hasil observasi dan wawancara, dianalisis menggunakan teknik deskriptif-kualitatif, yaitu mendeskripsikan lewat uraian dan penjelasan. Prosedur yang ditempuh dalam menganalisis data pada penelitian ini yakni (1) tabulasi data, (2) reduksi data, (3) deskripsi data, (4) klasifikasi data, dan (5) penarikan kesimpulan (Moelong, 2002). 
Penelitian ini menggunakan triangulasi teknik pengumpulan data. Menurut Sugiyono (2014) triangulasi teknik pengumpulan data merupakan penelitian yang menggunakan teknik pengumpulan data yang berbeda-beda untuk mendapatkan data dari sumber yang sama.

\section{Hasil dan Pembahasan}

Hasil observasi yang dilakukan dikelas Bahasa dan Budaya menunjukkan bahwa dalam pembelajaran membaca pemahaman di SMAN 4 Singaraja diberikan pada tahap ouyou renshuu (応用練習) atau latihan penerapan yang merupakan tahap terakhir dalam pembelajaran bahasa Jepang dasar yaitu dengan diberikan wacana sederhana yang akan dipahami oleh siswa. Dalam pembelajaran membaca pemahaman guru menerapkan strategi membaca dengan model Bottom-Up. Hal ini dilihat dari guru mengawali pembelajaran membaca dengan memahami bacaan dari tataran terendah yaitu mencari arti kosa kata, memahami setiap kalimat dalam paragraf yang terdapat dalam wacana hingga beranjak memahami isi atau informasi yang disampaikan pada wacana. Model membaca Bottom-Up digunakan karena siswa masih pada tahap pebelajar pemula dalam pembelajaran membaca pemahaman bahasa Jepang. Guru menyampaikan materi membaca pemahaman dengan gaya mengajar berbeda-beda disesuaikan dengan karakteristik siswa dimasing-masing kelas karena kemampuan membaca semua siswa tidak sama. Selain itu, guru juga menggunakan media pembelajaran berupa slide powerpoint yang berisi materi ajar seperti kosa kata, kalimat, dan gambar yang ditampilkan pada layar LCD yang bertujuan untuk meningkatkan minat dan motivasi siswa dalam pembelajaran membaca.

Proses pembelajaran membaca pemahaman yang dilaksanakan di SMAN 4 Singaraja menuntut siswa untuk lebih aktif karena pada proses pembelajaran membaca pemahaman guru memberikan instruksi kepada siswa bersama kelompoknya untuk menemukan sendiri isi dari wacana yang diberikan, sedangkan guru bertugas sebagai fasilitator untuk memperbaiki apabila terdapat pelafalan dan arti kosa kata yang keliru atau tidak tepat. Selain itu, untuk melatih siswa dalam membaca dan meningkatkan pemahaman siswa dalam proses membaca pemahaman, guru memperbanyak latihan membaca dari kosa kata hingga kalimat demi kalimat yang terkait dengan cara melafalkan, mencari arti kosa kata, dan mencoba membuat kalimat dengan pola kalimat yang diajarkan di dalam kelas.

Berdasarkan hasil wawancara yang diperoleh dari guru bahasa Jepang di SMAN 4 Singaraja bahwa guru bahasa Jepang SMAN 4 Singaraja sudah mengajar sejak tahun 2001 sampai sekarang. Bahasa Jepang di SMAN 4 Singaraja diajarkan pada jurusan IImu Bahasa dan Budaya (IBB), dan jurusan IImu Sosial (IS). Setiap siswa yang masuk ke dalam jurusan IBB akan mendapatkan pelajaran Bahasa Jepang sebagai mata pelajaran wajib mulai dari kelas X IBB, XI IBB, dan kelas XII IBB. Selain itu, terdapat juga lintas minat Bahasa Jepang di SMAN 4 Singaraja. Adapun yang memilih lintas minat Bahasa Jepang yaitu beberapa siswa yang berada dikelas X IS 1 , X IS 2 , dan XII IS 3 . Kriteria ketuntasan minimal (KKM) untuk bahasa Jepang di SMAN 4 Singaraja adalah 70.

Dalam pelajaran bahasa Jepang, buku pedoman yang digunakan siswa untuk menunjang pemahaman terhadap bahasa Jepang siswa di SMAN 4 Singaraja yaitu buku dari Japan Foundation, buku Sakura 1, Sakura 2, dan Sakura 3, serta buku pelajaran Bahasa Jepang (Nihongo) 1 dan Bahasa Jepang (Nihongo) 2. Selain buku pedoman tersebut, guru juga menggunakan buku lainnya seperti Minna No Nihon go dan Basic Kanji. Pelajaran bahasa Jepang direspon baik oleh siswa karena bagi siswa belajar bahasa Jepang merupakan pelajaran yang menarik.

Pendekatan yang digunakan guru bahasa Jepang di SMAN 4 Singaraja sesuai dengan kurikulum 2013 yaitu saintific. Di dalam mengajar bahasa Jepang, guru membedakan cara mengajar antara siswa jurusan IBB dan beberapa siswa yang memilih lintas minat bahasa Jepang. Untuk pelajaran bahasa Jepang siswa jurusan IBB (IImu Budaya dan Bahasa) lebih ditekankan karena pelajaran bahasa Jepang adalah pelajaran wajib diikuti oleh semua siswa IBB, sedangkan untuk lintas minat yang diikuti beberapa siswa jurusan IImu Sosial, pelajaran bahasa Jepang ini sedikit adanya kelonggaran karena memiliki latar belakang jurusan atau peminatan yang berbeda. 
Fokus penelitian yang dilakukan adalah tentang membaca pemahaman bahasa Jepang. Dalam hal ini, siswa yang mendapatkan pelajaran tentang membaca pemahaman wacana yaitu siswa IBB (ilmu Bahasa dan Budaya) kelas XI dan XII saja.

Strategi yang digunakan guru untuk mempermudah siswa dalam membaca pemahaman yaitu menerapkan model membaca Bottom-Up. Siswa diberi sebuah wacana baik ditampilkan pada layar LCD maupun memberikan lembaran yang berisikan teks wacana. Sebelum membaca wacana para siswa dihimbau untuk mencermati kosa kata yang sulit atau belum dimengerti kemudian membahas kosa kata tersebut secara bersama, selanjutnya siswa mulai membaca, mencermati dan memahami isi dalam wacana yang diberikan. Kemudian sebelum mengakhiri pelajaran guru menginstruksikan siswa menyimpulkan isi pokok yang terdapat pada wacana yang diberikan. Hal itu ditujukan untuk mengetahui sejauh mana pemahaman siswa terhadap teks wacana yang dipelajari. Pada akhir pembelajaran guru memberikan tugas rumah untuk membaca tulisan hiragana dan katakana maupun kanji dasar yang akan dipelajari pada saat pertemuan berikutnya. Hal tersebut membantu siswa agar lebih memahami wacana/bacaan yang akan dipelajari pada saat pertemuan berikutnya sehingga saat proses pembelajaran di kelas siswa lebih mudah untuk memahami wacana atau bacaan.

Media penunjang yang digunakan dalam pembelajaran membaca pemahaman bahasa Jepang di SMAN 4 Singaraja adalah LCD proyektor yang berisi bacaan-bacaan bahasa Jepang mulai dari kata, kalimat, paragraf, hingga sebuah wacana. Media tersebut digunakan untuk memfokuskan perhatian siswa terhadap apa yang sedang dipelajari.

Pembelajaran membaca disisipkan di setiap pertemuan. Di kelas XI ilmu Bahasa dan Budaya, guru melatih dengan membaca kosa kata hingga kalimat sederhana. Hal tersebut dilakukan agar kemampuan siswa terlatih dalam membaca bahasa Jepang sehingga saat diberikan sebuah wacana siswa dapat membaca dengan baik. Di kelas XII IImu Bahasa dan Budaya, Pembelajaran membaca lebih ditekankan seperti membaca huruf kanji dan membaca pemahaman teks wacana.

Latihan yang diberikan guru kepada siswa dalam pembelajaran membaca pemahaman tidak hanya sekedar dapat membaca wacana dengan baik, melainkan siswa dapat memahami isi wacana yang terkandung dalam teks wacana tersebut dan juga mengetahui terjemahannya dalam bahasa Indonesia. Namun latihan membaca pemahaman ini tidak diberikan setiap pertemuan dikarenakan pelajaran bahasa Jepang di SMAN 4 Singaraja tidak hanya memfokuskan siswa dalam hal membaca saja tetapi juga mengasah keterampilan berbicara, menulis dan mendengarkan karena keterampulan dalam berbahasa yang baik mencakup empat aspek tersebut. Pembelajaran membaca pemahaman juga akan dilatih pada jam tambahan bahasa Jepang yang disebut KSBK (Kelompok Siswa Binaan Khusus) yang dilakukan setiap hari jumat setelah jam sekolah berakhir yaitu jam 12.00 13.30 WITA. KSBK ini merupakan bimbingan siswa yang ditujukan untuk lomba-lomba bahasa Jepang seperti lomba Rodouku, Story Telling, Kana Cup, pidato Bahasa Jepang dan Lomba-lomba berbahasa Jepang lainnya. Jadi saat ada perlombaan yang diadakan baik yang diselenggarakan di kampus-kampus ataupun japan foundation jadi persiapan siswa SMAN 4 Singaraja untuk mengikuti setiap lomba sudah dipersiapkan sejak dini, hal ini merupakan salah satu cara guru bahasa Jepang SMAN 4 Singaraja membawa para siswa mendapatkan prestasi yang baik dalam keterampilan berbahasa Jepang. Prestasi yang diraih untuk tahun 2016 SMAN 4 Singaraja berhasil memperoleh juara 1 pidato bahasa Jepang dan juara 3 Roudoku yang diselenggarakan oleh Pendidikan bahasa Jepang UNDIKSHA pada bungkasai 10. Adapun prestasi-prestasi yang pernah diraih juga diantaranya juara 1 dan harapan 1 roudoku contest di UNDIKSHA pada tahun ajaran 2014/2015, juara 1 roudoku contest di UNDIKSHA pada tahun ajaran 2013/2014, dan juara harapan 1 roudoku contest di UNDIKSHA pada tahun ajaran 2012/2013. Kemudian juara 2 speech contest di UNDIKSHA, juara 1 story telling di STIBA, juara 2 story telling, dan juara 2 speech contest di Universitas Udayana, serta juara harapan lomba pidato yang diselenggarakan oleh Japan Foundation bekerjasama dengan MGMP bahasa Jepang.

Adapun cara guru mengevaluasi pelajaran membaca pemahaman dapat melalui tes yaitu secara tes tulis dan tes lisan. Evaluasi atau penilaian merupakan proses berhasil atau 
tidaknya siswa dalam proses pembelajaran. Evaluasi melalui tes tulis, yaitu siswa diberikan soal essay berdasarkan teks wacana yang dipelajari kemudian jawaban siswa dikumpulkan untuk diberi nilai. Nilai yang diperoleh siswa menjadi landasan guru untuk mengukur pemahaman siswa melalui tes tulis.

Evaluasi melalui tes lisan, dapat dilihat dari proses membaca siswa. Siswa diberikan wacana menggunakan huruf kana kemudian guru melakukan tanya jawab terkait wacana dan menunjuk siswa untuk bergantian membaca wacana perkalimat. Adapun aspek-aspek yang dinilai oleh guru dalam tes lisan adalah intonasi, kelancaran, pelafalan, tata bahasa, dan aksen. Dengan aspek tersebut guru dapat mengetahui kemampuan membaca siswa.

Berdasarkan hasil penelitian yang telah dipaparkan diatas, dapat diidentifikasi tiga temuan bermakna yang diperoleh dari hasil observasi dan wawancara, yaitu: 1) profil pembelajaran membaca pemahaman oleh guru bahasa Jepang di SMAN 4 Singaraja, 2) kendala yang dihadapi oleh guru dalam pembelajaran membaca pemahaman bahasa Jepang di SMAN 4 Singaraja, 3) upaya guru untuk mengatasi kendala dalam pembelajaran membaca pemahaman di SMAN 4 Singaraja. Tiga temuan ini akan dipaparkan secara rinci, sebagai berikut.

Profil pembelajaran membaca pemahaman oleh guru bahasa Jepang di SMAN 4 Singaraja dapat dilihat dari beberapa aspek penting, yaitu:

a. $\quad$ Kedudukan Pembelajaran Membaca Pemahaman di SMAN 4 Singaraja

Pembelajaran bahasa Jepang dasar yang diberikan pada pebelajar pemula terdiri dari tiga tahap dalam proses pembelajaran yaitu tahap dounyuu (導入) atau pengenalan, kihon renshuu (基本練習) atau latihan dasar, dan ouyou renshuu (応用練習) atau latihan penerapan (初級を教える, 2007:13). Secara umum dapat dikatakan bahwa pembelajaran membaca pemahaman merupakan implementasi dari 応用練習 (ouyou renshuu) atau tahap latihan penerapan dalam tahap pembelajaran bahasa Jepang dasar.

Pembelajaran membaca pemahaman sebagai ouyou renshuu dapat dikatakan bahwa membaca pemahaman berfungsi untuk menegaskan kembali pemahaman siswa terhadap kosa kata dan pola kalimat yang diajarkan pada tahap-tahap sebelumnya yaitu materi yang sudah dipahami pada tahap dounyuu (導入) dan diingat pada tahap kihon renshuu (基本練習).

Konsep dasar oyou renshuu adalah latihan penerapan atau penggunaan (tsukaeru). Sebagai latihan membaca pemahaman, guru memberikan bacaan bahasa Jepang sederhana yang disesuaikan dengan materi yang sudah dipelajari siswa.

\section{b. Tahapan Pembelajaran Membaca Pemahaman di Kelas}

Pada observasi yang dilakukan terlihat pembelajaran membaca pemahaman yang dilaksanakan di kelas dipaparkan sebagai berikut:

1. Mae Sagyou (前作業)

Guru lebih menekankan kepada kyoumi wo motaseru dibandingkan konsep gakususha ni kangaesaseru karena karakteristik siswa yang berbeda-beda. Kyoumi wo motaseru yaitu menarik minat siswa dalam membaca agar termotivasi dalam proses pembelajaran dengan menampilkan slide powerpoint berupa kosa kata dan gambar.

1. Tahap Mae Sagyou (前作業) merupakan tahap awal dalam kegiatan membaca. Proses pembelajaran pada tahap ini, guru memulai dengan tahap membaca yang paling mudah yaitu membaca kosa kata dan mencari arti kosa kata tersebut. Hal ini bertujuan untuk memberikan motivasi siswa dalam proses membaca pemahaman agar siswa mempunyai pengetahuan terkait kosa kata yang terdapat dalam teks bacaan yang akan dipelajari dan arti kosa kata tersebut dalam bahasa Indonesia, sehingga memudahkan siswa dalam proses pembelajaran membaca pemahaman. 
Saat proses pembelajaran, guru menampilkan slide powerpoint yang berisikan kosa kata-kosa kata baru yang terdapat pada teks yang akan dibahas. Hal ini sebagai salah satu strategi pembelajaran yang digunakan guru agar mampu memusatkan perhatian siswa dan meningkatkan minat dan motivasi siswa dalam proses pembelajaran. Selanjutnya, guru memberi kesempatan kepada siswa untuk mencoba latihan membaca dan mencari arti kosa kata yang ditampilkan pada slide powerpoint. Siswa juga diperbolehkan membuka kamus untuk mencari arti kosa kata-kosa kata lainnya yang tidak ditampilkan pada slide powerpoint yang tidak diketahui oleh siswa. Tujuannya agar mempermudah siswa dalam memahami isi di setiap kalimat dalam wacana yang akan dipelajari. Apabila siswa tidak ada yang mengangkat tangan saat diinstruksikan untuk latihan membaca kalimat maka, guru akan menunjuk siswa yang memiliki kemampuan baik dalam bahasa Jepang untuk memulai latihan yang diberikan oleh guru. Hal ini bertujuan untuk memotivasi siswa yang lain dalam proses pembelajaran dan menjadikan gambaran atau contoh untuk mencoba latihan yang diberikan guru bagi siswa yang berkemampuan kurang dalam bahasa Jepang dalam hal membaca.

Mengetahui arti pada setiap kosa kata merupakan salah satu aspek dalam membaca pemahaman bahasa Jepang atau (dokkai). Hal ini disebutkan oleh Kimura (dalam Apriani 2009:23) bahwa aspek membaca pemahaman diantaranya adalah mengetahui arti kata, dan mengetahui hubungan arti suatu kata dengan kata-kata lain dalam kalimat.

\section{Hon Sagyou (本作業)}

Tahap Hon Sagyou adalah pelaksanaan kegiatan membaca. Dalam tahap ini siswa harus memahami tujuan membaca dan berbagai strategi dalam proses membaca. Siswa diharapkan mampu memahami tujuan dari membaca yaitu menemukan informasi yang disampaikan dalam teks wacana. Tarigan (1979) mengatakan bahwa tujuan membaca adalah untuk mencari serta memperoleh informasi, mencakup isi, dan memahami makna bacaan. Strategi guru dalam proses membaca pemahaman yang diamati pada saat observasi yaitu guru menginstruksikan kepada semua siswa untuk memahami dan menerjemahkan setiap kalimat yang ada pada wacana setelah mengetahui arti kosa kata baru dan pola kalimat yang dipelajari sebelum proses membaca. Siswa yang ditunjuk akan membaca satu kalimat dalam wacana dan memaknai kalimat yang dibaca.

\section{Ato Sagyou (後作業)}

Tahap Ato Sagyou merupakan kegiatan setelah membaca pemahaman (dokkai) dilaksanakan. Dalam tahap ini, siswa diharapkan mampu menyimpulkan isi bacaan menurut pendapatnya sendiri tentang bacaan tersebut. Tahap ini dilakukan guru sebelum jam pelajaran berakhir. Tahap ini dilakukan dengan cara memberi kesempatan kepada siswa yang ingin menyimpulkan isi wacana dengan mengangkat tangan. Apabila siswa tidak ada yang mengangkat tangan, maka guru akan menunjuk beberapa siswa untuk menyimpulkan isi pokok wacana menurut pendapat masing-masing siswa dan jika ada yang kurang dengan kesimpulan atau pendapat dari siswa, maka guru menambahkan secara ringkas tentang informasi yang terdapat pada wacana.

c.Strategi Pembelajaran Membaca Pemahaman oleh Guru bahasa Jepang di SMAN 4 Singaraja

Strategi pembelajaran diperlukan guru untuk menunjang dalam proses belajar siswa menjadi lebih baik. Strategi pembelajaran membaca pemahaman digunakan guru bahasa Jepang SMAN 4 Singaraja untuk membantu siswa dalam membaca pemahaman bahasa Jepang dengan mudah.

Guru bahasa Jepang di SMAN 4 Singaraja menerapkan strategi pembelajaran membaca pemahaman bahasa Jepang dengan model membaca Bottom-Up. Model membaca Bottom-Up (dasar-atas) merupakan model membaca yang digunakan untuk pembaca pemula. Menurut model ini proses pemahaman teks dimulai dari tataran yang paling rendah menuju yang paling tinggi yaitu dimulai dari mengidentifikasi huruf-huruf, kata, frase dan kalimat, sehingga pembaca dapat memahami isi teks atau wacana. Dalam pembelajaran membaca pemahaman bahasa Jepang, guru memulai proses membaca dengan memahami kosa kata bahasa Jepang, kalimat menuju pemahaman wacana sederhana bahasa Jepang. 


\section{d. $\quad$ Evaluasi Pembelajaran Membaca Pemahaman di SMAN 4 Singaraja}

Mulyasa (2005) menyatakan bahwa evaluasi perlu dilakukan sebagai proses yang kontinu untuk memperbaiki pembelajaran dan membimbing pertumbuhan peserta didik.

Evaluasi pembelajaran membaca pemahaman bahasa Jepang di SMAN 4 Singaraja dilakukan dengan 2 cara, sebagai berikut:

Evaluasi melalui tes tulis, siswa diberikan soal essay berdasarkan teks wacana yang dipelajari kemudian jawaban siswa dikumpulkan untuk diberi nilai. Nilai yang diperoleh siswa menjadi landasan guru untuk mengukur pemahaman siswa melalui tes tulis.

Evaluasi melalui tes lisan, dapat dilihat dari proses membaca siswa. Siswa diberikan wacana menggunakan huruf kana kemudian guru melakukan tanya jawab terkait wacana dan menunjuk siswa untuk bergantian membaca wacana perkalimat. Aspek yang dinilai dalam tes lisan adalah intonasi, kelancaran, pelafalan, tata bahasa, aksen.

Kendala yang dialami guru dalam pembelajaran membaca pemahaman bahasa Jepang, sebagai berikut:

Kendala yang dialami oleh guru dalam proses membaca pemahaman yaitu masih sulit memotivasi siswa karena karakteristik siswa yang berbeda disetiap kelas seperti siswa yang kurang terhadap pemahaman kosa kata bahasa Jepang yaitu tulisan kanji, katakana dan hiragana. Maka, akan menemui kesulitan saat proses pembelajaran membaca pemahaman. Kemudian, kondisi kelas yang ribut merupakan kendala bagi guru dalam proses pembelajaran

Kendala berikutnya adalah kurangnya buku pedoman bahasa Jepang di SMAN 4 Singaraja untuk bahan ajar dalam pembelajaran membaca pemahaman bacaan. Buku bahasa Jepang yang digunakan di SMAN 4 Singaraja adalah buku Sakura, Nihongo, dan Minna no Nihongo.

Adapun cara guru untuk mengatasi kendala-kendala dalam pembelajaran membaca pemahaman bahasa Jepang yaitu guru memberikan banyak latihan membaca tulisan katakana, hiragana dan kanji baik berupa kosa kata-kosa kata dan kalimat sederhana. Selain itu juga untuk mengatasi kendala membaca guru memberikan tugas rumah sebelum jam pelajaran berakhir berupa latihan membaca kosa kata yang akan dipelajari pada pertemuan selanjutnya. Guru mengadakan variasi mengajar di kelas dengan mengondisikan karakter siswa disetiap kelas dan menggunakan strategi pembelajaran membaca pemahaman dengan model membaca Bottom-Up kepada siswa.

Apabila ada bahan ajar yang kurang dalam pembelajaran membaca pemahaman bahasa Jepang, guru mencari bahan tersebut melalui internet sebagai bahan ajar dalam pembelajaran seperti mencari wacana bahasa Jepang sederhana yang akan dipelajari oleh siswa yang disesuaikan dengan materi dan tema yang dipelajari siswa. Apabila terdapat kosa kata yang tidak dipahami oleh siswa maka, guru akan membahas secara bersamasama kosa kata tersebut.

\section{Simpulan dan Saran}

Simpulan

Adapun simpulan dalam penelitian ini, sebagai berikut.

Pembelajaran membaca pemahaman di SMAN 4 Singaraja merupakan implementasi dari ouyou renshuu dalam pembelajaran bahasa Jepang dasar. Meskipun sebagai ouyou rensahuu, guru memberikan pembelajaran membaca pemahaman secara khusus. Kekhasan dalam konsep membaca pemahaman seperti ini adalah bahan yang digunakan guru dalam pembelajaran membaca pemahaman disesuaikan dengan materi yang dibahas.

Guru menerapkan strategi pembelajaran membaca dengan menggunakan Bottom-Up. Hal ini disebabkan karena pemberian materi pada pembelajaran membaca pemahaman dimulai dari tataran yang paling rendah menuju tataran yang tinggi yaitu memulai dengan memahami kosa kata kemudian memahami kalimat hingga beranjak pada pemahaman isi bacaan. Penggunaan strategi membaca Bottom Up didasari oleh siswa masih pada tahap pemula dalam pembelajaran membaca pemahaman bahasa Jepang. 
Guru menggunakan media powerpoint berupa kosa kata dan gambar yang ditampilkan pada layar LCD sebagai media pembelajaran. Penggunaan media pembelajaran ini bertujuan untuk meningkatkan motivasi dan minat belajar siswa dalam pembelajaran membaca pemahaman bahasa Jepang di kelas.

Kendala yang dialami oleh guru dalam proses membaca pemahaman yaitu masih sulit menemukan strategi pembelajaran yang tepat dalam pembelajaran membaca pemahaman untuk memotivasi siswa karena karakteristik siswa yang berbeda dimasing-masing kelas, seperti siswa yang terkendala dalam membaca tulisan kanji, katakana dan hiragana. Kemudian, buku pedoman bahasa Jepang di SMAN 4 Singaraja masih terbilang sedikit untuk pembelajaran membaca pemahaman bacaan.

Guru mengatasi kendala-kendala pembelajaran membaca pemahaman dengan banyak memberikan latihan membaca tulisan kanji, katakana, dan hiragana baik berupa kosa katakosa kata dan kalimat sederhana. Guru mengadakan variasi mengajar di kelas dengan menyesuaikan karakter siswa dimasing-masing kelas dan menggunakan strategi pembelajaran membaca pemahaman dengan model membaca Bottom-Up.

\section{Saran} ini.

Sesuai temuan-temuan dalam penelitian ini, penulis dapat menyarankan hal-hal, berikut

1. Dalam proses pembelajaran, tentu terdapat kendala yang akan dihadapi guru maupun siswa. Adanya kendala dalam proses pembelajaran merupakan tantangan bagi guru agar selalu meningkatkan kualitas pembelajaran menjadi lebih baik.

2. Guru sebagai pendidik diharapkan mampu menemukan strategi pembelajaran yang sesuai dengan karakter dan kemampuan siswa, menmguasi materi ajar, dan menggunakan media pembelajaran yang menarik agar siswa dapat memahami materi dengan baik dan tidak merasa jenuh dalam proses pembelajaran berlangsung.

3. Guru juga diharapkan mampu memotivasi siswa agar minat dan semangat siswa dalam belajar terpacu serta giat belajar.

4. Penelitian ini diharapkan mampu menjadi referensi dalam penelitian selanjutnya yaitu dalam hal meneliti strategi pembelajaran dan media pembelajaran yang lebih variatif dalam penelitian profil pembelajaran membaca, serta meneliti aspek lain yang belum dipaparkan dalam penelitian ini.

\section{Daftar Pustaka}

Ananda, A.A., Dahidi, A. \& Juangsih. 2016. Korelasi penggunaan strategi membaca selektif terhadap kemampuan membaca pemahaman teks pendek dokkai (penelitian deskriptif pada mahasiswa tingkat ii tahun ajaran 2014/2015). Jurnal Pendidikan dan Pengajaran Bahasa Jepang. 1(1): 1-15. Tersedia pada http://ejournal.upi.edu/index.php/japanedu/article/view/ 2657/1745 (diakses pada 1 Desember 2017).

Apriani, R. 2009. Penerapan metode SQ3R (survey question read recite review) dalam membaca pemahaman teks bahasa jepang (dokkai). Skripsi. Tersedia pada http://repository.upi.edu/1283 (diakses pada 16 Desember 2017).

Bungin, B. 2009. Penelitian Kualitatif. Jakarta: Kencana.

Moelong, L. J. 2002. Metodologi penelitian kualitatif. Bandung: PT Remaja Rosdakarya.

Mulyasa, E. 2005. Menjadi guru professional. Bandung: Remaja Rosdakarya.

Nurkamilah, S. H., Aneros, N., \& Dewi, M. 2016. Efektivitas metode PQ4R teknik "temukan kesalahannya dulu" dalam pembelajaran membaca bahasa jepang siswa kelas xi sman 15 bandung tahun ajaran 2015/2016. Jurnal Pendidikan dan Pengajaran Bahasa Jepang. 1(2). Tersedia pada http://ejournal.upi.edu/index.php/japanedu/article/view/3836/2734 (diakses pada 16 Januari 2018). 
Romafi., \& Musfiroh, T. 2015. Hubungan minat membaca, fasilitas orang tua, dan pemberian tugas membaca dengan kemampuan membaca pemahaman siswa. Lingtera. 2(2). Tersedia pada https://journal.uny.ac.id/ index.php/ljtp/article/view/7377/6378 (diakses pada 1 desember 2017).

Sriwulan, N.A., Marhaeni, A.A.I.N., \& Yudana, I.M. 2014. Pengaruh model pembelajaran kooperatif tipe student teams achievement division (STAD) terhadap kemampuan membaca wacana bahasa jepang dengan kovariabel tingkat kecemasan siswa kelas xii/ipb sma negeri 1 semarapura. E-Journal Program Pasca Sarjana Universitas Pendidikan Ganesha. 4.4 pada http://pasca.undiksha.ac.id/ejournal/index.php/jurnalep/article/view File/1223/955 (diakses pada 1 Juli 2016).

Sugiyono. 2012. Metode Penelitian Kuantitatif, Kualitatif, dan R \& D. Bandung: Alfabeta

Sugiyono. 2014. Metode Penelitian Kuantitatif, Kualitatif, dan R \& D. Bandung: Alfabeta

Tarigan, Henry Guntur. 1979. Membaca sebagai Suatu Keterampilan Berbahasa . Bandung: Angkasa

Warner, G.J., Fay, D., dan Sporer, N. 2017. "Relations among personal initiative and the development of reading strategy knowledge and reading comprehension". Tersedia pada https://journals.sfu.ca/flr/index.php/journal/article/view/272/342 (diakses tanggal 19 september 2017). 